\title{
Haematological and Biochemical Profile of Wistar Rats Exposed to Chloroform Stem Extract of Portulaca oleracea Linn. (Purslane)
}

\author{
Victoria C. Obinna $^{1 *}$ and Gabriel O. Agu ${ }^{1}$ \\ ${ }^{1}$ Animal Health and Physiology Unit, Department of Animal and Environmental Biology, \\ Faculty of Science, University of Port Harcourt, Port Harcourt, Rivers State, Nigeria.
}

\begin{abstract}
Authors' contributions
This work was carried out in collaboration between both authors. Author VCO designed and carried out the study, performed the statistical analysis and wrote the manuscript. Author GOA supervised the study, managed the analyses of the study and proofread the manuscript. Both authors read and approved the final manuscript.

Article Information

DOI: $10.9734 / A R R B / 2021 / v 36 i 730394$ Editor(s):

(1) Dr. Bechan Sharma, University of Allahabad, India Reviewers:

(1) Lilik Retna Kartikasari, Universitas Sebelas Maret (UNS), Indonesia.

(2) Mohamed M Rhagem, University of Zawia, Libya. Complete Peer review History: https://www.sdiarticle4.com/review-history/69076
\end{abstract}

Original Research Article

Received 05 April 2021

Accepted 11 June 2021

Published 10 July 2021

\begin{abstract}
Portulaca oleracea Linn. has a history of extensive use as a medicinal plant and is a component of the Nigerian ethnomedical pharmacopoeia. Although several studies have been carried out exclusively on the leaves to ascertain the physiological effect, there seems to be dearth of literature on the physiological effect of the stem. This study which was designed to fill this gap investigated the sub-chronic effect of oral administration of chloroform stem extract of P.oleracea (CSEPO) on haematological parameters and plasma activities of some enzymes (Alanine Aminotransferase ALT, Alkaline Phosphatase - ALP \& Aspartate Aminotransferase - AST) and levels of other biochemical parameters such as total protein, albumin, bilirubin, urea and creatinine in male wistar rats. Twenty animals were randomly divided into 4 groups of 5 rats each. Group $\mathrm{A}(\mathrm{Control})$ received $0.5 \mathrm{ml}$ of olive oil(vehicle) while Groups $B, C \& D$ received 125,250 \& $500 \mathrm{mg} / \mathrm{kg}$ body weight of CSEPO respectively for 21 days by oral gavage. At the end, the animals were anaesthetized and blood samples were collected for haematology and plasma biochemical assay. No significant $(P>.05)$ variation occurred in the mean values of ALT, ALP, AST, total protein,
\end{abstract}


albumin, bilirubin, urea, creatinine, Packed Cell Volume (PCV), haemoglobin concentration, RBC, WBC and differential leucocyte counts relative to the control. There was a highly significant $(P<$ .01) increase in the total platelet count only at the dose of $500 \mathrm{mg} / \mathrm{kg}$ in comparison with control. Oral administration of CSEPO as used in this study had no adverse effect on haematological and biochemical parameters. Secondly, CSEPO may be a useful remedy in thrombocytopenia, due to its potential to increase platelet count. However, further study is recommended in that regards.

Keywords: Portulaca oleracea; ALT; AST; ALP; blood; urea; creatinine; platelet.

\section{INTRODUCTION}

The use of plants and herbs as food supplements and medicine is fast gaining ground and recognition globally. Plants that are readily available and affordable are usually used indiscriminately and excessively for these purposes [1,2] due to the popular opinion that "for every health challenge, there is a remedial plant". This unguided constant resort to plants, which are considered safe due to the common belief that natural is better [3] may result in detrimental effect on the physiology of vital body organs. Therefore, there is a need to find out if these indigenous plants are safe, especially, at the excessive quantities consumed.

Portulaca oleracea Linn. has a history of extensive use as a medicinal plant [4,5]. Different parts of the plant have been associated with various physiological properties. Some studies have been carried out exclusively on the leaves [6-9], stem + leaves [10,11], aerial parts [12,13] and whole plant $[14,15]$ to establish their physiological effects; but to the best of our knowledge, none was done solely on the stem. The study was therefore designed to investigate the effect of oral administration of chloroform stem extract of Portulaca oleracea (CSEPO) on haematological and biochemical parameters in male wistar rats.

\section{MATERIALS AND METHODS}

\subsection{Plant Material and Authentication}

Fresh stems of Portulaca oleracea Linn. were collected from Alakahia axis of Port Harcourt, Nigeria. The plant was identified at the University of Port Harcourt Herbarium, Department of Plant Science and Biotechnology, with Herbarium number - UPH/V/1,302.

\subsection{Preparation of the Stem Extract}

The collected plant stems were shade-dried at room temperature to constant weight over a period of twelve weeks. The dried stems were weighed and ground to fine powder. The stem extract was obtained by cold maceration using chloroform. Briefly, the powdered stems were soaked in chloroform $(500 \mathrm{~g}$ stem powder in $1.5 \mathrm{~L}$ solvent) for 72 hours with fresh replacement of solvent every 24 hours. The pooled extract was filtered with the Watman's No. 1 filter paper. The filtrate was concentrated with a rotary evaporator (Model No: RE-52A) at $45^{\circ} \mathrm{C}$ in vacuo and later transferred to an evaporating dish and dried over a water bath (Digital thermostatic water bath, Jinotech instruments). The obtained extract was stored in a desiccator. All reagents used were of analytical grades.

\subsection{Acute Toxicity Study}

The acute toxicity testing of the extract was evaluated according to the method of Lorke [16].

\subsection{Animals and Treatment}

Twenty mature male wistar rats weighing an average of $190 \mathrm{~g}$, purchased from the Animal House of Department of Pharmacology, College of Health Sciences, University of Port Harcourt were used for this study. The rats were acclimatized for two weeks before the study was commenced. They were housed in wooden cages under standard conditions of $28^{\circ} \mathrm{C}$ ambient temperature and approximately 12- hr natural light-dark cycle, and fed ad libitum with commercially sourced feed (Top Feeds Nigeria Limited) and supplied with clean drinking water all through the study. The experimental procedures were in compliance with ARRIVE guidelines as reported by Kilkenny et al., [17].

After acclimatization, the animals were randomly assigned to four (4) groups - A, B, C and D. Group A served as the control and was given 0.5 $\mathrm{ml}$ of olive oil (vehicle) while the treatment groups B, C and D received 125, 250 and 500 $\mathrm{mg} / \mathrm{kg}$, respectively of CSEPO. Treatments were done daily by oral gavage for 21 days. 
At the end of the treatments, the animals were anaesthetized and blood samples were collected into EDTA bottles (for Haematology) and Heparin bottles (for plasma biochemical profile). The collected blood samples in EDTA bottles were used for the estimation of haematological parameters such as packed cell volume (PCV), haemoglobin concentration $(\mathrm{Hb})$, red blood cell count (RBC), white blood cell count (WBC), platelets count, lymphocyte and neutrophil levels according to Cheesebrough [18]. The blood samples collected into heparinized bottles was used for determining the plasma activity of Alanine Aminotransferase (ALT), Aspartate Aminotransferase (AST) and Alkaline Phosphatase (ALP), as well as the levels of total protein, Albumin, total and conjugated bilirubin, creatinine, urea, sodium, potassium, chloride and bicarbonate. The blood was centrifuged at 4000 rpm for 10 mins after which the plasma was separated from the cells and tipped into a separate vial. The vial was placed in microcentrifuge tubes, capped and stored at $20^{\circ} \mathrm{C}$ until analysis. The plasma biochemistry determinations were done using commercial test kits.

The activities of ALT and AST were measured according to the method of Reitman and Frankel [19] while the serum ALP activity was determined by the thymolphthalein monophosphate method according to Roy [20]. The total bilirubin and conjugated bilirubin were determined by Jendrassik-Grof method [21] while the total protein (TP) was determined by the direct Biuret method [22]. The albumin was assayed using the bromocresol green method [23] while urea and creatinine were evaluated with the Urease Berthelot method [24] and the modified Jaffe method [25] respectively.

\subsection{Statistical Analysis}

Statistical analysis was done using SPSS 21. All values were expressed as mean \pm SEM and data were assessed by one-way ANOVA followed by the Tukey post-test. The significance level was set at $95 \%$ confidence interval.

\section{RESULTS}

The Acute toxicity study showed that Chloroform stem extract of P.oleracea was well tolerated at the maximum dose of $5000 \mathrm{mg} / \mathrm{kg}$ body weight, no mortality or any sign of toxicity was observed hence the $1 / 40^{\text {th }}, 1 / 20^{\text {th }}$ and $1 / 10^{\text {th }}$ of $5000 \mathrm{mg} / \mathrm{kg}$ $(125,250$ and $500 \mathrm{mg} / \mathrm{kg}$ ) were adopted as doses for the study.

The effect of oral administration of chloroform stem extract of Portulaca oleracea on the haematological and biochemical profile of male wistar rats are summarized in Table 1 and Figs. $1-8$ respectively.

Treatment of rats for 21days with 125, 250 and $500 \mathrm{mg} / \mathrm{kg}$ doses of CSEPO had no significant effect on the blood parameters relative to the control as shown in Table 1. However, at the highest dose of $500 \mathrm{mg} / \mathrm{kg}$, CSEPO caused a marked significant $(P<.01)$ increase in total platelet count in comparison with the control.

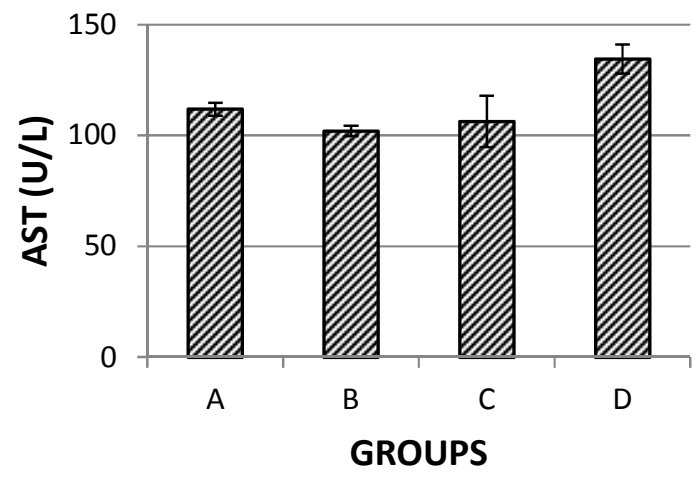

Fig. 1. Effect of chloroform stem extract of Portulaca oleracea Linn. on Aspartate aminotransferase (AST) in male wistar rats

Results are given as mean \pm SEM for 5 rats in each group. Experimental groups are compared with group $A$ (control). No significant difference at $95 \%$ confidence interval $(P>.05)$. Groups $A, B, C$ and $D$ represent the control (given $0.5 \mathrm{ml}$ olive oil), $125 \mathrm{mg} / \mathrm{kg}$ CSEPO-treated rats, $250 \mathrm{mg} / \mathrm{kg}$ CSEPO-treated rats and $500 \mathrm{mg} / \mathrm{kg}$ CSEPO-treated rats, respectively 
Obinna and Agu; ARRB, 36(7): 1-11, 2021; Article no.ARRB.69076

Table 1. Haematological profile of male wistar rats exposed to oral administration of chloroform stem extract of Portulaca oleracea Linn. for 21 days

\begin{tabular}{|c|c|c|c|c|c|c|c|c|c|}
\hline Groups & PCV (\%) & $\mathrm{Hb}(\mathrm{g} / \mathrm{dL})$ & $\begin{array}{l}\text { RBC } \\
\left(X 10^{12} / L\right)\end{array}$ & $\begin{array}{l}\text { WBC } \\
\left(X 10^{9} / L\right)\end{array}$ & $\begin{array}{l}\text { PLATELET } \\
\left(\mathrm{X} 10^{9} / \mathrm{L}\right)\end{array}$ & NEUT (\%) & LYMP (\%) & EOSIN (\%) & MONO (\%) \\
\hline A & $39.80 \pm 2.48$ & $13.26 \pm 0.82$ & $5.86 \pm 0.42$ & $8.38 \pm 0.84$ & $199.80 \pm 10.11$ & $23.20 \pm 1.24$ & $64.60 \pm 1.63$ & $3.60 \pm 0.60$ & $8.60 \pm 0.60$ \\
\hline $\mathrm{B}$ & $38.20 \pm 0.97$ & $12.72 \pm 0.31$ & $5.70 \pm 0.15$ & $9.10 \pm 0.50$ & $217.40 \pm 13.68$ & $27.20 \pm 2.82$ & $62.40 \pm 2.50$ & $3.00 \pm 0.45$ & $7.40 \pm 0.40$ \\
\hline C & $36.20 \pm 1.56$ & $12.08 \pm 0.53$ & $5.28 \pm 0.31$ & $11.30 \pm 1.21$ & $249.80 \pm 14.84$ & $27.20 \pm 1.77$ & $60.60 \pm 1.69$ & $4.40 \pm 0.40$ & $7.80 \pm 0.66$ \\
\hline $\mathrm{D}$ & $36.75 \pm 2.93$ & $12.28 \pm 0.98$ & $5.15 \pm 0.49$ & $10.78 \pm 1.87$ & $278.75 \pm 16.25^{\star *}$ & $25.50 \pm 2.10$ & $64.25 \pm 2.17$ & $2.75 \pm 0.48$ & $7.50 \pm 0.50$ \\
\hline
\end{tabular}




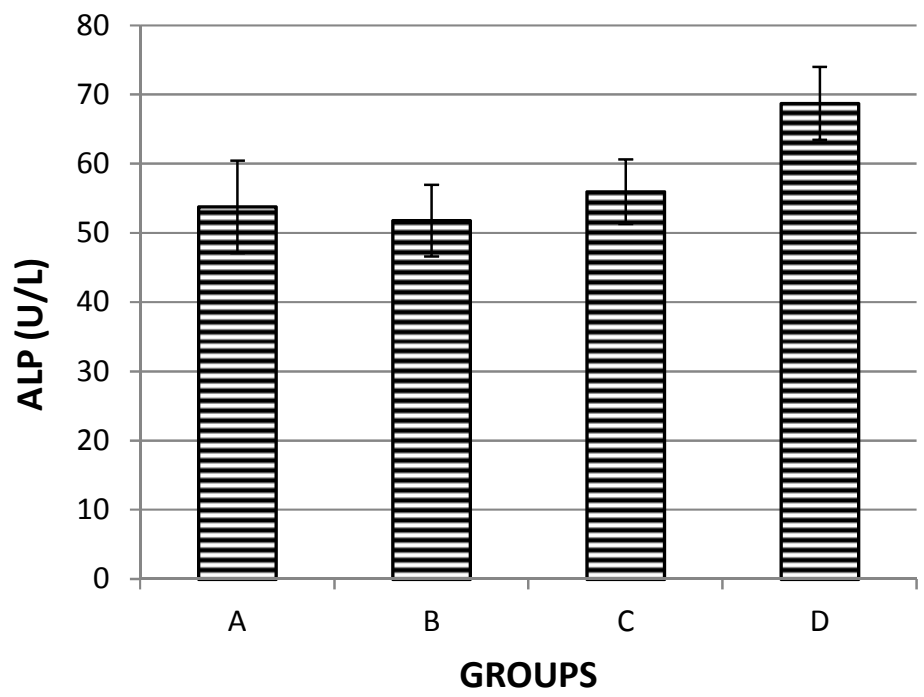

Fig. 2. Effect of chloroform Stem extract of Portulaca oleracea Linn. on Alkaline phosphatase (ALP) in male wistar rats

Results are given as mean \pm SEM for 5 rats in each group. Experimental groups are compared with group $A$ (control). No significant difference at $95 \%$ confidence interval $(P>.05)$. Groups $A, B, C$ and $D$ represent the control (given $0.5 \mathrm{ml}$ olive oil), $125 \mathrm{mg} / \mathrm{kg}$ CSEPO-treated rats, $250 \mathrm{mg} / \mathrm{kg}$ CSEPO-treated rats and $50 \mathrm{mg} / \mathrm{kg}$ CSEPO-treated rats, respectively

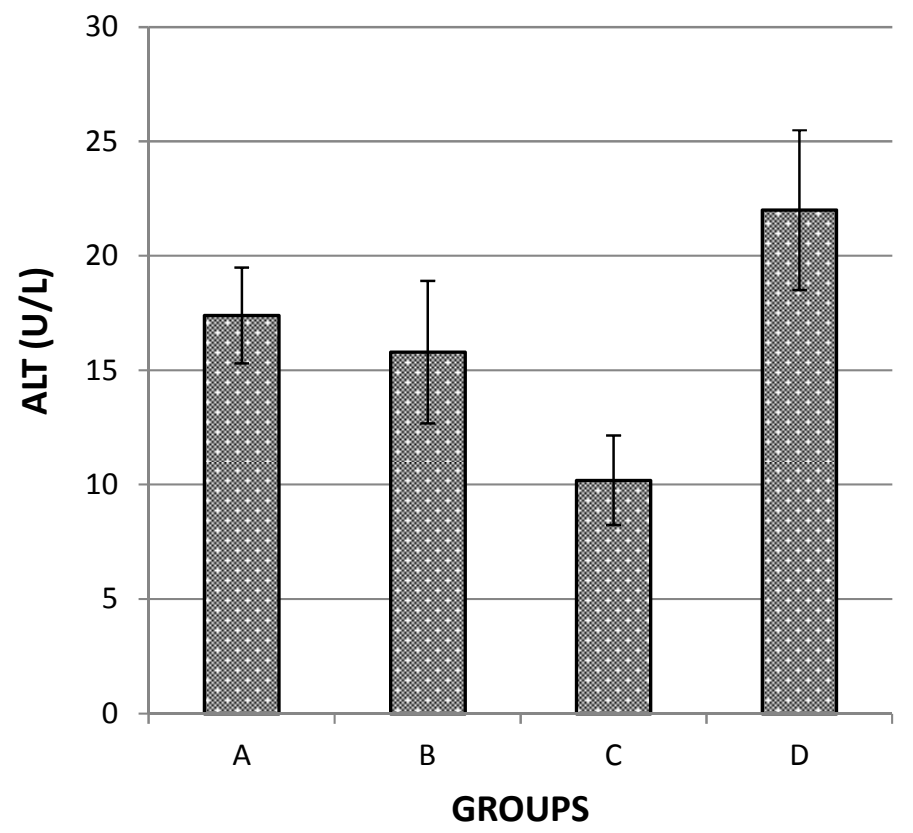

Fig. 3. Effect of chloroform stem extract of Portulaca oleracea Linn. on Alanine aminotransferase (ALT) in male wistar rats

Results are given as mean \pm SEM for 5 rats in each group. Experimental groups are compared with group $A$ (control). No significant difference at $95 \%$ confidence interval $(P>.05)$. Groups $A, B, C$ and $D$ represent the control (given $0.5 \mathrm{ml}$ olive oil), $125 \mathrm{mg} / \mathrm{kg}$ CSEPO-treated rats, $250 \mathrm{mg} / \mathrm{kg}$ CSEPO-treated rats and $500 \mathrm{mg} / \mathrm{kg}$ CSEPO-treated rats, respectively 


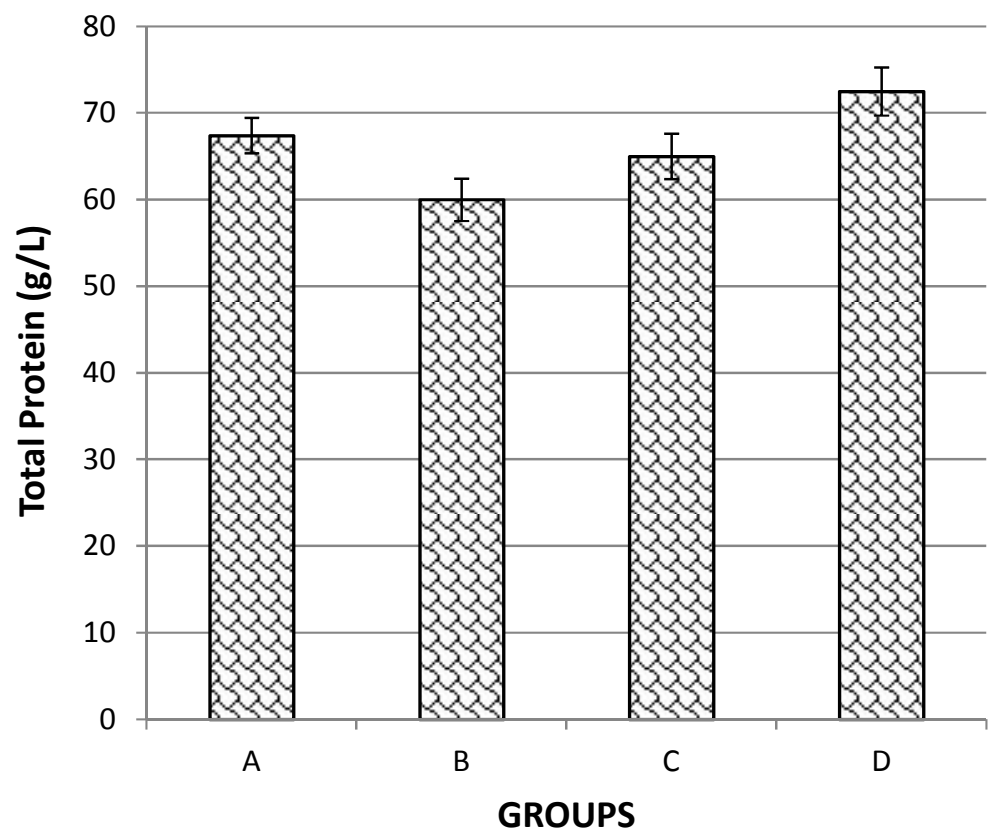

Fig. 4. Effect of chloroform stem extract of Portulaca oleracea Linn. on total protein level in male wistar rats

Results are given as mean \pm SEM for 5 rats in each group. Experimental groups are compared with group $A$ (control). No significant difference at $95 \%$ confidence interval $(P>.05)$. Groups $A, B, C$ and $D$ represent the control (given $0.5 \mathrm{ml}$ olive oil), $125 \mathrm{mg} / \mathrm{kg}$ CSEPO-treated rats, $250 \mathrm{mg} / \mathrm{kg}$ CSEPO-treated rats and $500 \mathrm{mg} / \mathrm{kg}$ CSEPO-treated rats, respectively

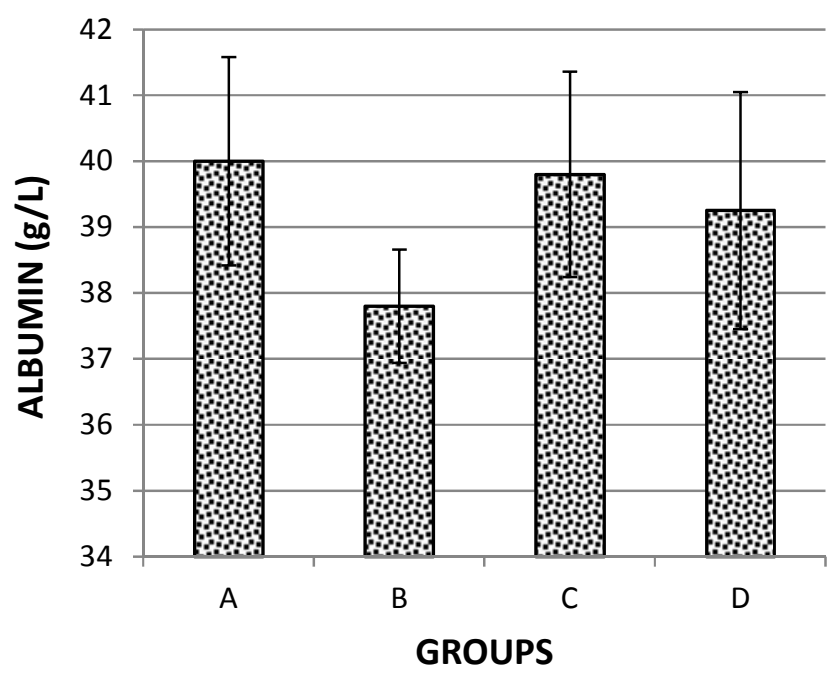

Fig. 5. Effect of chloroform stem extract of Portulaca oleracea Linn. on albumin level in male wistar rats

Results are given as mean \pm SEM for 5 rats in each group. Experimental groups are compared with group $A$ (control). No significant difference at $95 \%$ confidence interval $(P>.05)$. Groups $A, B, C$ and $D$ represent the control (given $0.5 \mathrm{ml}$ olive oil), $125 \mathrm{mg} / \mathrm{kg}$ CSEPO-treated rats, 250mg/kg CSEPO-treated rats and $500 \mathrm{mg} / \mathrm{kg}$ CSEPO-treated rats, respectively. 


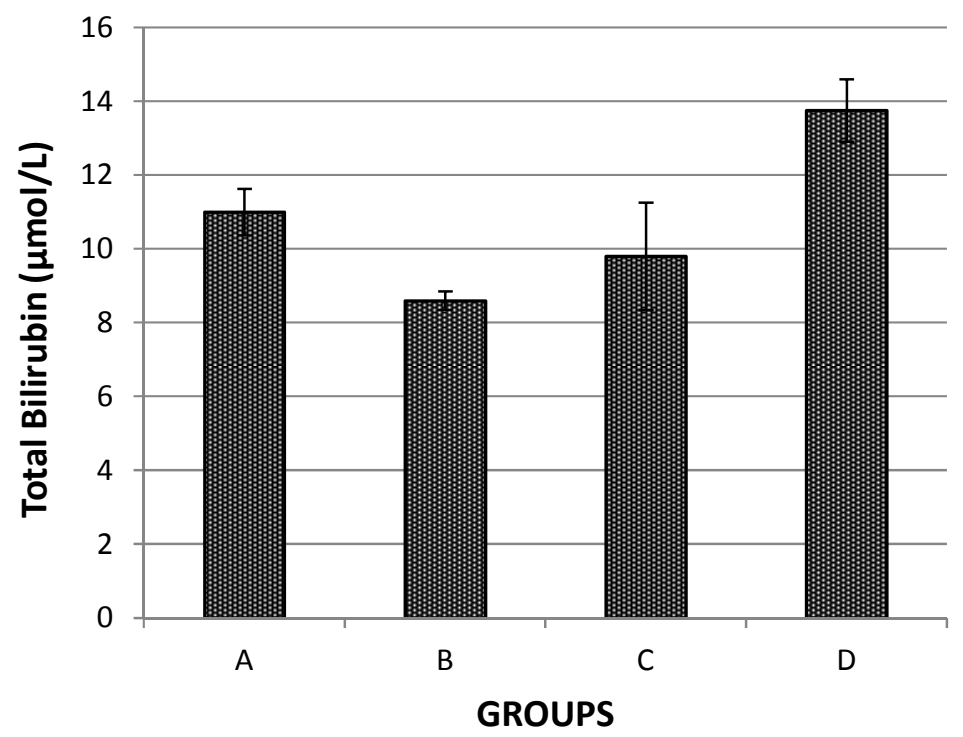

Fig. 6. Effect of chloroform stem extract of Portulaca oleracea Linn. on total bilirubin level in male wistar rats

Results are given as mean \pm SEM for 5 rats in each group. Experimental groups are compared with group $A$ (control). No significant difference at $95 \%$ confidence interval $(P>.05)$. Groups $A, B, C$ and $D$ represent the control (given $0.5 \mathrm{ml}$ olive oil), $125 \mathrm{mg} / \mathrm{kg}$ CSEPO-treated rats, $250 \mathrm{mg} / \mathrm{kg}$ CSEPO-treated rats and $500 \mathrm{mg} / \mathrm{kg}$ CSEPO-treated rats, respectively

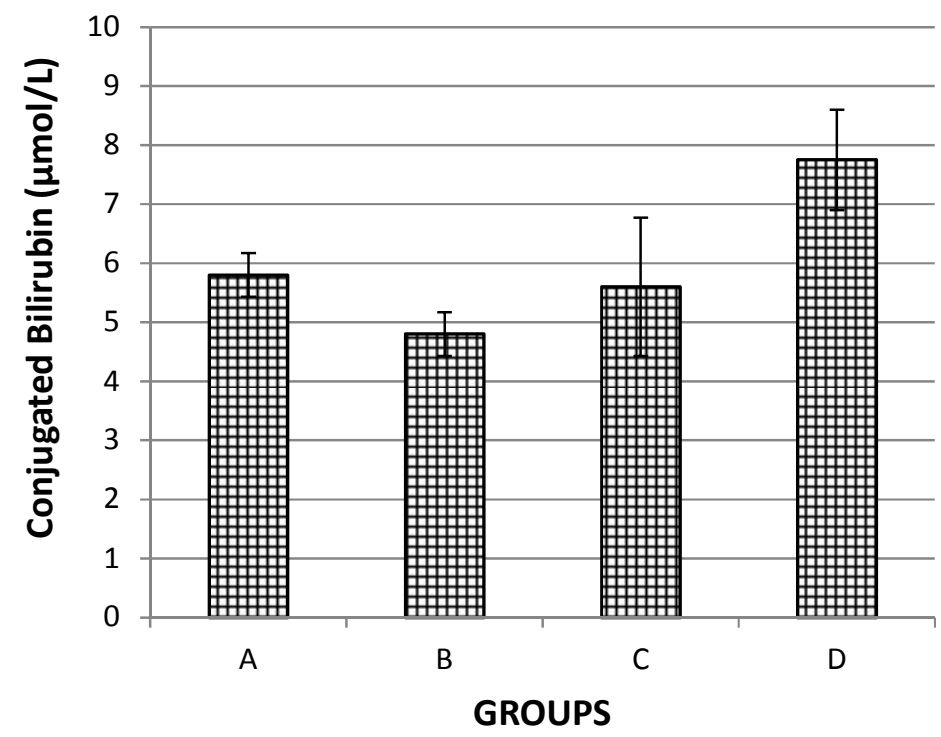

Fig. 7. Effect of chloroform stem extract of Portulaca oleracea Linn. on conjugated bilirubin level in male wistar rats

Results are given as mean \pm SEM for 5 rats in each group. Experimental groups are compared with group $A$ (control). No significant difference at $95 \%$ confidence interval $(P>.05)$. Groups $A, B, C$ and $D$ represent the control (given $0.5 \mathrm{ml}$ olive oil), $125 \mathrm{mg} / \mathrm{kg}$ CSEPO-treated rats, $250 \mathrm{mg} / \mathrm{kg}$ CSEPO-treated rats and $500 \mathrm{mg} / \mathrm{kg}$ CSEPO-treated rats, respectively 


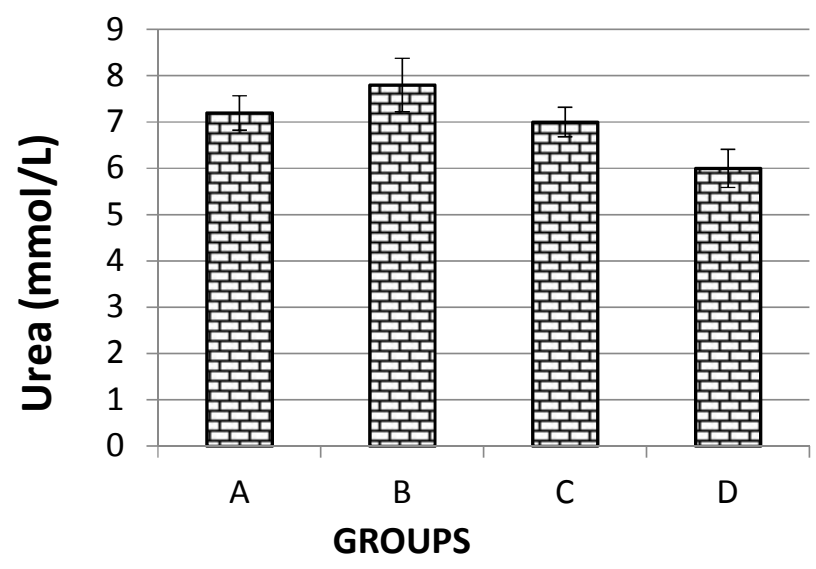

Fig. 8. Effect of chloroform stem extract of Portulaca oleracea Linn. on urea level in male wistar rats

Results are given as mean \pm SEM for 5 rats in each group. Experimental groups are compared with group $A$ (control). No significant difference at $95 \%$ confidence interval $(P>.05)$. Groups $A, B, C$ and $D$ represent the control (given $0.5 \mathrm{ml}$ olive oil), $125 \mathrm{mg} / \mathrm{kg}$ CSEPO-treated rats, $250 \mathrm{mg} / \mathrm{kg}$ CSEPO-treated rats and $500 \mathrm{mg} / \mathrm{kg}$ CSEPO-treated rats, respectively

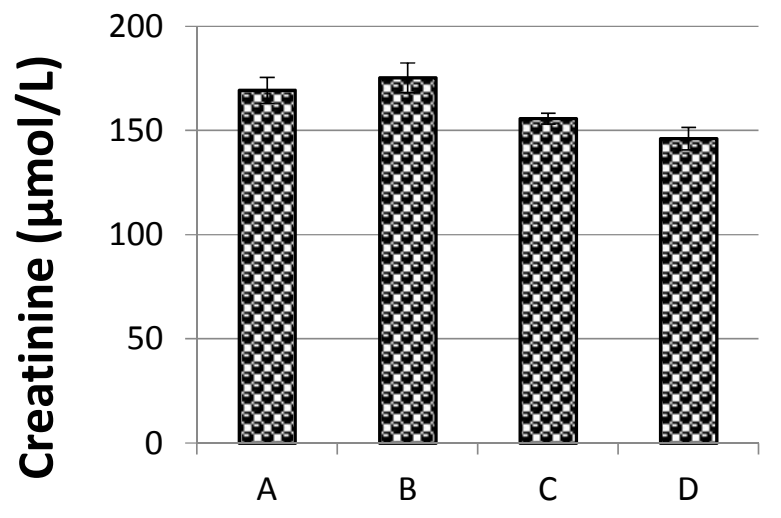

GROUPS

Fig. 9. Effect of chloroform stem extract of Portulaca oleracea Linn. on creatinine level in male wistar rats

Results are given as mean \pm SEM for 5 rats in each group. Experimental groups are compared with group $A$ (control). No significant difference at $95 \%$ confidence interval $(P>.05)$. Groups $A, B, C$ and $D$ represent the control (given $0.5 \mathrm{ml}$ olive oil), $125 \mathrm{mg} / \mathrm{kg}$ CSEPO-treated rats, $250 \mathrm{mg} / \mathrm{kg}$ CSEPO-treated rats and $500 \mathrm{mg} / \mathrm{kg}$ CSEPO-treated rats, respectively

CSEPO made no significant $(P>.05)$ difference in the plasma levels of ALT, ALP and AST in the treated rats when compared with the control (Figs. 1-3). Similarly, there was no significant ( $P>$ .05) difference in the plasma concentration of total protein, albumin, bilirubin (total and conjugate), urea and creatinine of exposed rats in relation with the control as shown in Figs. 4-8.

\section{DISCUSSION}

Haematological and blood biochemical parameters are health markers which aid diagnoses and the evaluation of physiological and pathological status of animals. Blood which is a fundamental component as well as the major transport system of the body is used to detect any disorder or anomaly arising from exposure to 
all forms of injuries [26]. Serum / Plasma biochemical tests provide information on the functional state of the internal organs of the body such as liver, kidney, heart and muscle.

The result of this study showed that the haematological parameters of all the CSEPO treated rats were not different from the control, except that the platelet count was highly increased at the dose of $500 \mathrm{mg} / \mathrm{kg}$. This finding agrees with the previous work on Portulaca oleracea leaves which also found that chloroform leaf extract of $P$. oleracea administered by oral gavage to rats for 60 days at the same doses had no significant effect on the haematological parameters although the total platelet count increased significantly at the dose of $500 \mathrm{mg} / \mathrm{kg}$ on day 60 [6]. This marked elevation in platelet count in the current study occurred at a shorter duration of 21 days as opposed to the longer duration of 60 days reported in the previous study. This rapid onset of action may be attributed to an active substance in the stem which might be in trace amount in the leaf since the extracts of both plant parts elicited an increase in platelet count.

The occurrence of high platelet count could lead to the formation of clots in the blood vessels; a condition usually associated with cancer, irondeficiency anaemia, inflammatory disorder and infections such as tuberculosis [27]. Although the exact cause for this marked increase in the platelet count is unknown, it is supposed that the increase is not associated with any of the aforementioned disease conditions since the blood parameters such as PCV, haemoglobin concentration, RBC and WBC counts; which are markers for anaemia, infection and inflammation, were not altered.

From studies, it has been found that some medicinal plants may be useful remedies for thrombocytopenia as they have the potential to increase platelet count [28-30]. According to Kasture et al. [31], leaf extract of Carica papaya markedly elevated the platelet count in patients with thrombocytopenia associated with dengue fever with fewer side effects and good tolerability. Sequel to these reports, it can be inferred that P.oleracea stem may possess thrombopoietin properties based on its potential to increase platelet count and as such, may also be useful in alleviating thrombocytopenia.

The result of this study also shows that the chloroform stem extract of $P$. oleracea had no significant effect on the biochemical profile of exposed rats at the different doses and duration used in the study, unlike the leaf counterpart which altered the ALP and AST levels at different doses and duration; a significant decrease in AST level at the dose of $250 \mathrm{mg} / \mathrm{kg}$ on Day 28 and a significant increase in ALP at the dose of $500 \mathrm{mg} / \mathrm{kg}$ on Days 14 and 60 [7]. This finding suggests that the stem extract may lack the potential to reduce the plasma levels of the enzymes - AST, ALT and ALP by stabilizing the cell membrane of the source, in order to prevent the seepage of these enzymes, even in the absence of injury. According to Okoye et al. [32], the relatively lower serum activity of ALT, AST, and ALP observed in rats treated with methanol extract of $T$. occidentalis was attributed to cell membrane stabilizing activity of the extract. Injury to liver cell membrane leads to the release of cytosol enzymes such as AST, ALT and ALP into the blood. ALT is more specific to the liver because AST may also be elevated in diseases affecting other organs, such as the heart or muscles [7]. Similarly, ALP is abundant in several organs including liver, bone, kidney, intestine, and placenta and its major increase is associated with liver and bone dysfunctions [33].

A comparison of the acute oral toxicity testing of $P$. oleracea leaves in the previous studies $[6,7]$ with $P$. oleracea stem in the present study, reveals that the chloroform extracts of both plant parts are not toxic since they were well tolerated by the animals at the maximum dose of 5000 $\mathrm{mg} / \mathrm{kg}$.

\section{CONCLUSION}

The absence of adverse effect on haematological and plasma biochemical profile of the CSEPO treated rats suggests that the stem extract is relatively safe as there is no indication of injury, abnormalities in the metabolic processes and extract-related stress in the animals. Secondly, the significant elevation in platelet count shows that CSEPO may be a useful remedy in thrombocytopenia. Further study is recommended to validate this finding.

\section{CONSENT}

It is not applicable.

\section{ETHICAL APPROVAL}

The study protocols were duly approved by the Research Ethics Committee of the Centre for Research Management and Development, 
University of Port Harcourt with the Ref. No: UPH/CEREMAD/REC/04. The rats for the study were humanely handled in accordance with the Ethics and Regulation guiding the use of research animals as approved by the University.

\section{ACKNOWLEDGEMENT}

The authors acknowledge Dr. A.E. Afieroho of the Department of Pharmacognosy, University of Port Harcourt, for his assistance in this research.

\section{COMPETING INTERESTS}

Authors have declared that no competing interests exist.

\section{REFERENCES}

1. Bekalo $\mathrm{TH}$, Woodmatas SD, Woldemariam ZA. An ethnobotanical study of medicinal plants used by local people in the lowlands of Konta Special Woreda , southern nations, nationalities and peoples regional state, Ethiopia. J Ethnobiol Ethnomed. 2009;5.

DOI: https://doi.org/10.1186/1746-4269-526

2. Eswaran S, Boomibalagan P, Rathinavel S. Ethnoveterinary medicinal practices of the villagers of Usilampatti Taluk of Madurai District, India. Int $\mathrm{J}$ Bot. 2013;9:37-43.

DOI: https://doi.org/10.3923/ijb.2013.37.43

3. Saalu LC. Nigerian folklore medicinal plants with potential antifertility activity in males: A scientific appraisal. Res J Med Plants. 2016;10:201-27.

DOI:

https://doi.org/10.3923/rjmp.2016.201.227

4. Samarghandian S, Borji A, Farkhondeh T. Attenuation of oxidative stress and inflammation by portulaca oleracea in streptozotocin-induced diabetic rats. J Evidence-Based Complement Altern Med. 2017;22:562-6.

DOI:https://doi.org/10.1177/215658721769 2491

5. Okafor IA, Ayalokunrin MB, Abu OL. A review on Portulaca oleracea (purslane) plant - Its nature and biomedical benefits. Int J Biomed Res. 2014;5:75-80.

DOI:https://doi.org/10.7439/ijbr

6. Obinna VC, Kagbo HD, Agu GO. Effects of chloroform leaf extracts of Portulaca oleracea Linn. (purslane) on haematological parameters in albino wistar rats. J Complement Altern Med Res. 2018;6:1-8.

DOI:https://doi.org/10.9734/JOCAMR/2018 143996

7. Obinna VC, Kagbo HD, Agu GO. Hepatic and renal biochemical profile of albino rats exposed to chloroform and methanol leaf extracts of Portulaca oleracea Linn. European J Med Plants. 2018; 25:1-14. DOI:https://doi.org/10.9734/EJMP/2018/43 846

8. Obinna VC, Kagbo HD, Afieroho OE, Agu GO. Haematological profile of albino rats exposed to polar leaf extracts of Portulaca. GSC Biol Pharm Sci. 2019;07: 75-85. DOI:https://doi.org/10.30574/gscbps.2019. 7.1.0042

9. Naseeruddin SD, Kumar S, Jagan Rao N. Acute toxicity and diuretic studies of pet ether extract of Portulaca oleracea (Linn.). Int J Anal Pharm Biomed Sci. 2013;2:61-3.

10. Oyedeji KO, Bolarinwa AF. Effects of crude extracts of portulaca oleracea on haematological and biochemical parameters in albino rats. African $\mathrm{J}$ Biomed Res. 2012;15:41-7.

11. Nayaka HB, Londonkar RL, Andumesh MK. Evaluation of portulaca oleracea I for anti-fertility effect in female albino rats. Int J Pharm Pharm Sci. 2014;6:86-9.

12. Rashed AN, Afifi FU, Disi AM. Simple evaluation of the wound healing activity of a crude extract of Portulaca oleracea $L$. (growing in Jordan) in Mus musculus JVI1. J Ethnopharmacol. 2003;88:131-6. DOI:10.1016/S0378-8741(03)00194-6

13. Ahangarpour A, Lamoochi Z, Moghaddam HF, Mansouri MT. Effects of Portulaca oleracea ethanolic extract on reproductive system of aging female mice. Int J Reprod Med. 2016;14:205-12.

14. Dkhil MA, Moniem AEA, Al-Quraishy S, Saleh RA. Antioxidant effect of purslane (Portulaca oleracea) and its mechanism of action. J Med Plants Res. 2011;5:1589-93. DOI:10.1108/01443580410569235

15. Shafi S, Tabassum N. Preliminary phytochemical screening, renal and haematological effects of Portulaca oleracea (Whole Plant) in Swiss albino mice. Int Res J Pharm. 2015;6:349-53. DOI:10.7897/2230-8407.06672

16. Lorke D. A new approach to practical acute toxicity testing. Arch Toxicol. 1983;54:27587. 
17. Kilkenny C, Browne WJ, Cuthill IC, Emerson M, Altman DG. Improving Bioscience Research reporting: The ARRIVE guidelines for reporting animal research. PLoS Biol. 2010;8:6-10.

DOI: 10.1371/journal.pbio.1000412

18. Cheesebrough M. District laboratory practice in tropical countries. Cambridge: Cambridge University Press; 2006.

19. Reitman S, Frankel SA. A colorimetric method for the determination of serum glutamic oxalacetic and glutamic pyruvic transaminases. Am J Clin Pathol. 1957;28:56-63.

DOI: https://doi.org/10.1093/ajcp/28.1.56

20. Roy AV. Rapid method for determining alkaline phosphatase activity in serum with thymolphthalein monophosphate. Clin Chem. 1970;16:431-6.

21. Jendrassik L, P. Grof. estimation of total serum bilirubin level by spectrophotometrically in serum and plasma. Biochem Zeits. 1938;297: 81-9.

22. Carol A, Bell M. Clinical guide to laboratory tests. 3rd ed. Phildelphia: WB Saunders Company; 1995.

23. Doumas BT, Watson WA, Biggs HG. Albumin standards and the measurement of serum albumin with bromcresol green. Clin Chim Acta Int J Clin Chem. 1971;31:87-96.

24. Fawcett JK, Scott JE. A rapid and precise method for the determination of urea. J Clin Pathol. 1960;13:156-9.

25. Blass KG, Thibert RJ, Lam LK. A study of the mechanism of the Jaffe reaction. Clin Chem Lab Med. 1974;12:336-43.

DOI:https://doi.org/10.1515/cclm.1974.12.7 .336

26. Obinna VC, Agu GO. Haematological effect of toluene in wistar rats. J Sci Res Reports 2019;25:1-7.

DOI:https://doi.org/10.9734/JSRR/2019/v2 $5 i 4301932$
27. Gaspard KJ. Disorders of haemostasis. In: Porth CM, editor. Essentials Pathophysiol. 3rd ed., Philadelphia, USA: Wolters Kluwer Health / Lippincott Williams \& Wilkins. 2011:263-78.

28. Hasan Z, Quadir R, Eva EO, Khanam M. Platelet raising effect of ipomoea batatas (Sweet Potato) Leaf Extract in Rats. EMCJ. 2016;1:9-12.

29. Venkataraman N, Pamukuntia S, Banoth J, Boini $P$, Sampathi $S$, Swami V, et al. Platelet augmentation activity of andrographis paniculata extract and andrographolide against cyclophosphamide induced thrombocytopenia in rats. Pharm Pharmacol Intern J. 2015;2:126-31.

DOI: 10.15406/ppij.2015.02.00029

30. Atik NUR, Tarawifa S, Avriyanti E, Rahmadi AR, Hilmanto D. Psidium Guajava L . Extract increases platelet count through enhancement of stem cell factor expression in thrombocytopenic mice model. Int $\mathrm{J}$ Pharm Pharm Sci. 2018;10:12-5.

31. Kasture PN, Nagabhushan $\mathrm{KH}$, Kumar A. A multi-centric, double-blind, placebocontrolled, randomized, prospective study to evaluate the efficacy and safety of carica papaya leaf extract, as empirical therapy for thrombocytopenia associated with dengue fever. J Assoc Physicians India. 2016;64:15-20.

32. Okoye $\mathrm{CN}$, Ihedioha JI, Agina OA, Ochiogu I, Ogwu D. Hepatoprotective and nephrotoxic effects of methanol leaf extract of Telfairia occidentalis (Hook f.) in adult female albino rats (Rattus norvegicus). Thai J Pharm Sci. 2016;40:167-71.

33. Kaid F, Alabsi AM, Alafifi N, Ali-saeed R, Al-koshab MA, Ramanathan $A$, et al. Effects of goniothalamin on selective internal organs of male sprague-dawley rats. J Toxicol. 2019;2019:13. DOI: https://doi.org/10.1155/2019/6493286

(c) 2021 Obinna and Agu; This is an Open Access article distributed under the terms of the Creative Commons Attribution License (http://creativecommons.org/licenses/by/4.0), which permits unrestricted use, distribution, and reproduction in any medium, provided the original work is properly cited.

Peer-review history:

The peer review history for this paper can be accessed here: https://www.sdiarticle4.com/review-history/69076 